found within the overall cost of the new contract."2 Addressing the conference, Mr D E Bolt, the consultants' chief negotiator, has put the record straight on this naive and damaging Whitehall evidence, about which the Representative Body will also have some angry comments to make. Certainly, by pricing 13 NHDs as the standard week instead of 10 as the profession wanted the Review Body has made the contract unattractive to consultants. This serious devaluation of the NHD has been aggravated by two other decisions. Three of those 13 NHDs would have no long-term security of tenure, and the emergency recall fees have been priced with money obtained by reducing the basic salary - a change that has also been recommended for the existing contract. So, despite a highly critical leading article in the Guardian calling the award to consultants excessive, the new contract is in jeopardy. GPs have also been angered by being told that, because their indirect expenses have been overpaid for the last three years, this year the increase awarded is only $£ 200$-a sum that will barely cover some doctors' higher petrol costs-thus reducing their net remuneration increase to around $18 \%$ on average. So it is highly probable that the $\mathrm{RB}$ will react unfavourably to a report that doctors had looked forward to as repairing some of the damage inflicted on doctors' incomes since 1975.

This Ninth Report will not be an auspicious start to the profession's relations with the new Government. Nor will it make life easy for the profession's leaders, though no one could have worked harder than they for doctors. But politics is a harsh business, and a major task at Liverpool will be to persuade the profession's representatives to keep their cool in deciding how best to overcome this setback.

1 British Medical fournal, 1979, 1, 1502.

2 Review Body on Doctors and Dentists' Remuneration, Ninth Report, Cmnd 7574. London, HMSO, 1979.

3 British Medical fournal, 1978, 2, 301.

4 Guardian, 7 June 1979, 12.

\section{Treatment of angioedema}

Hereditary angioedema is characterised by recurrent attacks of localised oedema affecting skin and mucosal surfaces. Oedema of the skin, though distressing, is not usually dangerous; but oedema affecting the gastrointestinal mucosa may present as intestinal obstruction, while oedema of the mucosa of the upper respiratory tract (the "oedema glottidis" mentioned by Osler ${ }^{1}$ in his description of the condition) may threaten life. Hereditary angioedema is an uncommon disease, inherited as an autosomal dominant. A form of angioedema with similar clinical features has been found in cases of lymphosarcoma, ${ }^{2}$ chronic lymphatic leukaemia, ${ }^{3}$ and rectal carcinoma. ${ }^{4}$

The primary biochemical fault in both hereditary and acquired angioedema associated with cancer is deficiency or abnormality of an inhibitor in the complement pathway. ${ }^{2} 56$ Like the coagulation system, the complement pathway consists of a "cascade," precursor proteins being converted by specific proteolytic reactions to a series of active enzymes. Thus $\mathrm{Cl}$ is converted to $\mathrm{Cl}$ esterase, and this acts on $\mathrm{C} 4$ and $\mathrm{C} 2$ to activate the rest of the classical complement pathway (which consists of the nine proteins $\mathrm{Cl}-\mathrm{C9}$ ). This pathway is the major effector mechanism of the antibody response, and its activation leads to the destruction of foreign cells and to acute inflammation. Regulation of the system depends in part on inhibitors in the serum. The inhibitor of $\mathrm{Cl}$ esterase (C1 INH), for example, prevents conversion of $\mathrm{Cl}$ to $\mathrm{Cl}$ esterase by binding with $\mathrm{Cl}$. This is the inhibitor affected in angioedema. In hereditary angioedema $80 \%$ of patients have only $5-30 \%$ of the normal concentration of $\mathrm{Cl}$ INH; the rest have a normal concentration of a non-functioning protein antigenically identical to $\mathrm{Cl} \mathrm{INH}$. In acquired angioedema the complement profile includes a low $\mathrm{Cl}$ concentration as well as low $\mathrm{Cl} \mathrm{INH}, \mathrm{C} 2$, and $\mathrm{C} 4$ concentrations.

Clinical attacks of angioedema, which are usually selflimiting, are attributed to activation of $\mathrm{Cl}$, consumption of $\mathrm{C} 2$ and $\mathrm{C} 4$, and release of a vasoactive peptide, possibly from C2. Some attacks are spontaneous while others follow trauma, which triggers the fibrinolytic pathway and releases plasmin to activate $\mathrm{Cl}$ esterase. ${ }^{78}$ Treatment with plasmin inhibitors such as epsilon-aminocaproic acid $^{9}$ and tranexamic acid ${ }^{10}$ reduces the number of attacks but does not entirely prevent them. An alternative approach is to give androgens, which correct the low concentrations of $\mathrm{Cl} \mathrm{INH}$, probably by inducing its synthesis. This provides effective prophylaxis ${ }^{11}{ }^{12}$; but the use of androgens, particularly methyltestosterone, is limited by the dangers of masculinisation and damage to the liver. Danazol, an androgen derivative with minimal virilising properties, is, however, highly efficacious in preventing attacks $^{13}$ : the drug raises the concentration of $\mathrm{Cl}$ INH and restores that of $\mathrm{C} 4$ to the normal range.

Recently, Cohen et al have reported the successful use of danazol in a patient who had acquired angioedema associated with a rectal carcinoma. ${ }^{4} \mathrm{He}$ had had two episodes of laryngeal oedema requiring intubation, and an abnormal complement profile, before the rectal adenocarcinoma was found. After resection of the tumour laryngeal oedema recurred. When treatment with danazol was started the complement concentrations returned to normal and the patient remained free of attacks even though the $\mathrm{Cl}$ INH subsequently fell to pretreatment concentrations. This anomaly suggests that danazol may interfere with activation of $\mathrm{Cl}$ as well as increasing C1 INH production initially.

Danazol, then, is proving to be an effective treatment for a potentially fatal condition. We still need, however, to answer questions about the "switching on" and "switching off" of the complement pathway. The answers may suggest methods to overcome the unsolved problem of treating or reversing attacks of angioedema once they have begun.

1 Osler, W, American fournal of Medical Science, 1888, 95, 362.

2 Caldwell, J R, et al, Clinical Immunology and Immunopathology, 1972, 1, 39.

3 Day, N K, et al, Clinical Experimental Immunology, 1976, 26, 189.

${ }^{4}$ Cohen, S H, et al, fournal of Allergy and Clinical Immunology, 1978, 62, 217.

5 Donaldson, V H, and Evans, R R, American fournal of Medicine, 1963, 35, 37.

${ }^{6}$ Rosen, F S, et al, Science, 1965, 148, 957.

7 Pillemer, L, Ratnoff, O D, and Lepon, I H, fournal of Experimental Medicine, 1953, 97, 573.

${ }^{8}$ Ratnoff, O D, and Naff, G M, Fournal of Experimental Medicine, 1967, 125, 337.

9 Frank, M M, et al, New England fournal of Medicine, 1972, 286, 808.

10 Sheffer, A L, Austen, K F, and Rosen, F S, New England Fournal of Medicine, 1972, 287, 452.

11 Spaulding, W B, Annals of Internal Medicine, 1960, 53, 739.

12 Sheffer, A L, Fearson, D T, and Austen, K F, Annals of Internal Medicine, 1977, 86, 306.

13 Gelfand, J A, et al, New England fournal of Medicine, 1976, 295, 1444. 